\title{
Lack of evidence of porcine reproductive and respiratory syndrome virus (PRRSV) infection in domestic swine in Brazil
}

\author{
Ausência de infecção pelo vírus da síndrome reprodutiva e respiratória dos suínos (PRRS) \\ em suínos domésticos no Brasil
}

\author{
Janice Reis Ciacci-Zanella ${ }^{1}$ Cristiano Trombetta ${ }^{2}$ Ildara Vargas ${ }^{3}$ \\ Denise Euclydes Mariano da Costa ${ }^{4}$
}

\section{ABSTRACT}

This report describes the first prevalence of antibodies and experimental inoculation of suspected samples of porcine reproductive and respiratory syndrome virus (PRRSV) from ELISA positive pigs from swine herds in Brazil. Based on the hypothesis that this agent is present in swine herds worldwide, the objective of this work was to establish a diagnostic methodology and to investigate the occurrence of PRRSV in Brazilian swine herds. Fifty-four swine herds, the total number which imported genetic material (live pigs or swine semen) from countries where PRRS was endemic from 1990 to December 2000, from eight Brazilian States all included in this study. The sampling used was such as to detect a prevalence of infection of 5\%, with a confidence level of $95 \%$. A total of 3785 serum samples were tested for PRRSV antibodies by ELISA. Following the ELISA test, which was performed with two different commercial kits, all serum positive pigs were retested, examined and additional materials were collected. Viral isolation in permissive tissue culture cells and swine bioassays were performed. Additionally reverse transcriptase polymerase chain reaction (RT-PCR) and nested RT-PCR were also performed. We could not demonstrate the presence of PRRSV or RNA of PRRSV by viral isolation or RT-PCR (or nested RT-PCR), respectively in all of the analyzed samples. Furthermore, the pigs inoculated with PRRSV suspicion samples did not seroconvert nor produce characteristic PRRS lesions in the swine bioassay. Thus, our results indicate no evidence of PRRSV in the samples analyzed from swine herds in this study.

Key Words: PRRS, porcine reproductive and respiratory syndrome, serological survey, PRRSV, porcine reproductive and respiratory syndrome virus, Brazil.

\section{RESUMO}

Este artigo descreve a primeira prevalência de anticorpos e inoculação experimental de amostras suspeitas do vírus da síndrome reprodutiva e respiratória dos suínos (PRRSV) de suínos de rebanhos do Brasil positivos pelo teste de ELISA. Com base na hipótese de que este agente está presente em plantéis de suínos mundialmente, o objetivo deste trabalho foi estabelecer uma metodologia de diagnóstico e também investigar a ocorrência de PRRSV em rebanhos suínos brasileiros. Cinqüenta e quatro granjas, número total de granjas que importaram material genético (suínos vivos e sêmen suíno) de países onde a PRRS era endêmica no período de 1990 a dezembro de 2000, de oito estados brasileiros foram todas incluídas neste estudo. $O$ tamanho da amostragem de soros coletados foi para que se detectasse uma prevalência de 5\%, com um nível de confiança de 95\%. Um total de 3785 amostras de soro foram testadas para detecção de anticorpos para PRRSV por ELISA. Após a realização dos testes de ELISA, os quais foram realizados utilizando dois kits comerciais, todos os suínos positivos foram retestados sorologicamente, examinados e depois, material adicional foi coletado para detecção viral. O material para isolamento viral foi inoculado em células de cultivo permissiveis e também em suínos (bio-ensaio suíno). Além disso, reação de transcriptase reversa e reação da polimerase em cadeia (RT-PCR) e nested RT-PCR também foram realizadas. Não foi demonstrada a presença de PRRSV ou de RNA de PRRSV por isolamento viral ou RT-PCR (ou nested $R T-P C R)$, respectivamente, em todas as amostras testadas. Além disso, os suínos inoculados com amostras suspeitas de PRRSV não soro-converteram ou produziram lesões características de PRRS no bio-ensaio suíno. Portanto, nossos resultados não indicam evidências da presença de PRRSV nas amostras analisadas dos rebanhos suínos deste estudo.

\footnotetext{
${ }^{1}$ Veterinarian, MSc., PhD., Researcher at Embrapa Swine and Poultry Research Center, CP 21, 89.700-000, Concórdia, SC, Brazil. E-mail: janice@cnpsa.embrapa.br Corresponding author.

${ }^{2}$ Undergraduate student of Biological Sciences at the Univesidade do Contestado, Campus Concórdia, SC, Fellowship of Embrapa Swine and Poultry Research Center Brazil.

${ }^{3}$ Veterinarian, Coordinator of Animal Health Programs at the Brazilian Agriculture, Animal and Food Supply Ministry, Animal Health and Agriculture Secretary, Brasilia, DF, Brazil.

${ }^{4}$ Veterinarian, MSc., Director of the Department of Animal Defense and Animal Health and Agriculture Secretary of the Brazilian Agriculture, Animal and Food Supply Ministry, Brasília, DF, Brazil.
} 
Palavras-chave: $P R R S$, síndrome reprodutiva e respiratória dos suínos, levantamento sorológico, PRRSV, virus da síndrome reprodutiva $e$ respiratória dos suínos, Brasil.

\section{INTRODUCTION}

In order to improve the genetics of breeding herds, Brazilian hog producers imported genetic material (semen and live animals) originating from countries which are recognized by their genetic technology, such as the North American and Europeans countries. However, this trade could have brought serious problems for the health status of swine Brazilian herds, such as the entrance of disease causing agents present in those countries but not in Brazil, such as the PRRS virus (PRRSV).

PRRSV is an enveloped RNA virus with a genome of $15 \mathrm{~Kb}$, containing 7 open reading frames (ORFs), with 45 to $65 \mathrm{~nm}$ of diameter. The ORF 7 encodes a nucleocapsid protein which induces a strong immune response, and it is conserved among different PRRSV isolates. Based on viral genome organization, replication strategy, protein composition and nucleotide sequence, the virus has been included in the Arteriviridae family (MEULENBERG et al., 1993).

PRRS was first described in the United States in 1987 (KEFFABER, 1989), in Europe in 1990 (WENSVOORT et al., 1991) and later in Asia. The disease was initially called Mystery Disease or Swine Infertility and Respiratory Syndrome (SIRS) (GOYAL, 1993). PRRS is clinically presented by anorexia and respiratory problems in swine of all ages, high mortality in newborn and weaned piglets, low conception rate in breeders and an increase in the abortion rate, stillborns and the occurrence of weak newborns (DONE et al., 1996). PRRSV was isolated in the Netherlands by WENSVOORT et al. (1991) and afterwards was identified in many countries around the world where it is endemic (COLLINS et al., 1992).

Although there are intranational and international regulations for the transit control of animals, notification of the disease, quarantine, elimination of affected animals, the virus continued to be disseminated around the world (DEWEY, 1997). Some countries have adopted the ELISA test for PRRSV for serological monitoring as a routine. However, those countries which have reported the occurrence of the virus in their herds had reductions in semen and breeders sale. In 1992 PRRS became a B level disease at OIE (International Office of Epizooties), which requires that country members must report their PRRSV status and their control methods (DEWEY, 1997). Other
South American countries such as Colombia, Venezuela and Chile, recently, have identified the occurrence of antibodies against PRRSV and typical signs of PRRS in their swine herds (DEWEY 1999; NARANJO, 2001). In all of those countries, the initial source of infection was the introduction, by importation, of infected swine at the beginning of the 90 's, or at the end of the 80 's, from countries where PRRS was present. In Chile, the viral RNA was identified by RT-PCR and the viral genome sequencing indicated that the Chilean isolate had significant homology with North American PRRSV isolates (NARANJO, 2001).

No disease has yet been reported in Brazil (DEWEY, 1997; 1998; 1999). Although ELISA tests have been performed in serum samples from Brazilian swine herds since 1994 with only negative results, no additional laboratory tests were performed (CIACCIZANELLA, 2001). Those studies were from 218 farms from several Brazilian States and a total of 4831 serum samples of swine on several stages of production (breeders, weaners and growers). DEWEY $(1998 ; 1999)$ confirms that a serum-prevalence study performed by a breeding company between 1996 and 1997 has reported only negative results. Since 1997, swine producers in Brazil have adopted some importation rules such as all imported pigs must be in quarantined, and during this period, be tested negative for PRRSV antibodies. The imported pigs must come from herds free of PRRSV, be tested negative for PRRSV at the origin and during quarantine in Brazil. The serological test used in Brazil is the PRRSV Elisa Herdchek imported from IDEXX (USA). This is a fast, sensitive test and identifies both North-American and European isolates. However, there are some disadvantages; due to importation rates it has become expensive and it may generate false-positive results, which requires retesting, thus compromising its specificity. Thus a precise and fast diagnostic is very important, because in the majority of the cases the pigs show no clinical symptoms but are viremic and consequently the virus can be disseminated. In addition to that, PRRS can be misdiagnosed with another viral diseases such as pseudorabies, swine influenza or porcine parvovirus, and this can affect the diagnosis and the control of this syndrome (DONE et al., 1996). The transmission of PRRSV may occur by aerosol, thus the dissemination among pigs in a herd can be fast. The virus may also be isolated from porcine semen, which indicates that PRRSV can be disseminated through artificial insemination (SWENSON et al., 1994; DONE et al., 1996). The presence of PRRSV in the porcine semen can be an additional source of infection and also 
introduction of the agent into the swine herd. This is an important point in the epidemiology of the disease and a problem for countries free of PRRSV but that import frozen semen from countries in which the virus is present.

In this paper we investigate the presence of antibodies for PRRSV in swine farms in Brazil which imported live pigs or swine semen from 1990 to December of 2000. This survey was a partnership between the Brazilian Ministry of Agriculture, Animal Production and Food Supply (MAPA) and the Embrapa Swine and Poultry Research Center. Swine serum originated from those swine farms were tested and when positive or suspicion samples were detected, further examinations were performed. Laboratory tests such as immunofluorescence antibody, viral isolation, swine bioassays and RT-PCR or nested RT-PCR were performed in order to detect PRRSV antibodies or to isolate PRRSV or identify PRRSV RNA.

\section{MATERIAL AND METHODS}

A total of 3785 swine serum samples from 54 different farms of eight Brazilian States (Rio Grande do Sul, Santa Catarina, Paraná, São Paulo, Minas Gerais, Mato Grosso, Mato Grosso do Sul and Goiás) were analyzed, being 3442 of the first sampling and 343 of the second. They were sent to the Animal Health Laboratory at Embrapa Swine and Poultry Research Center (Embrapa Suínos e Aves, Concórdia, Santa Catarina, Brazil) for serological tests using a commercial ELISA kit imported from IDEXX Laboratories (HerdChek* PRRS IDEXX ELISA test). The sampling was done at the breeding herd, considering an estimated prevalence of $5 \%$ and a confidence level of 95\%. Positive samples at the IDEXX ELISA test were also tested by the CIVTEST ${ }^{\mathrm{TM}}$ SUIS PRRS (HIPRA).

Immunofluorescence antibody (IFA) test was performed in MARC-145 cell cultures inoculated with PRRSV fixed slides (provided by Fernando Osório, University of Nebraska Lincoln, USA) performed as described previously (MENGELING et al., 1996).

For viral isolation attempts, tissues from the pigs were collected at necropsy (lung, tonsil, lymph nodes, among others), in addition to serum (MENGELING et al., 1995), blood, or tonsil fragment collected at biopsy (DEE \& MOLITOR, 1998). Tissues (and also tonsil fragment from biopsies) were pooled and homogenized in F10 - 199 medium containing penicillin $(100 \mathrm{U} / \mu \mathrm{l})$ and streptomycin $\left(100 \mu \mathrm{g} \mathrm{ml} \mathrm{g}^{-1}\right)$ to make approximately a $10 \%$ suspension. The sample was clarified, filtered through a $0.22 \mu \mathrm{m}$ - pore - size filter, and used as an inoculum. Blood collected in vials containing EDTA (Vacutainer cat \# 6432) was centrifuged to separate PBMC (peripheral blood mononuclear cells) by a single step gradient of FicollHypaque (NORTH \& HENRY, 1980). Viral isolation was carried out in MARC-145 cell culture [monkey kidney cells, (KIM et al., 1993)]. Flasks of $25 \mathrm{~cm}^{3}$ of semi-confluent MARC-145 cells were inoculated with $1 \mathrm{ml}$ of the inoculum, which could be organs suspension, or sera or $5 \times 10^{6}$ cells / $\mathrm{ml}$ of PBMC, and incubated for 1 hour at $37^{\circ} \mathrm{C}$ in $\mathrm{CO}_{2}$ atmosphere for virus adsorption. Then, $4 \mathrm{ml}$ of fresh complete medium (F10-199 medium supplemented with 5\% FCS and antibiotics) was added, and the flasks were incubated for an additional 16 hours. Following incubation, the complete medium was replaced and the cells were then incubated for a further $72 \mathrm{~h}$ (KIM et al., 1993; MENGELING et al., 1996).

RNA from serum or total blood was isolated from positive samples for PRRS antibodies using the TRIzol ${ }^{\circledR}$ Reagent (GibcoBRL). RNA from swine organs (lung, tonsil, lymph nodes, fetuses, umbilical cords, among others) previously kept frozen at $-80^{\circ} \mathrm{C}$ was isolated using the CHOMCZYNSKI \& SACCHI (1987) extraction method using guanidine thiocyanate (Promega), phenol and chloroform. Those two different methods were used for different sampling materials due to better RNA yield. The reverse transcriptase reaction and PCR amplification was carried out as described by ALLENDE et al. (2000). Primers used were designed from conserved sequences of the ORF7 (open reading frame 7) (MENG et al., 1995), which codes a viral nucleocapsid protein conserved among different PRRSV isolates (MEULENBERG et al., 1993). Another two sets of primers, outer and nested, derived also from ORF7 sequences, were used for nested RTPCR (CHRISTOPHER-HENNINGS et al., 1995). Positive control RNA used in these tests was RNA extracted from PRRSV cultivated in MARC- 145 cells (provided by Fernando Osório, University of Nebraska, Lincoln, USA).

Swine bioassay for the detection of PRRSV in suspicion samples and further reproduction of the disease was performed as described previously (CHRISTOPHER-HENNINGS et al., 1995). Ten 5 - to 10 day-old piglets seronegative for PRRSV antibodies and from seronegative PRRSV dams were kept in isolators with negative pressure for a period of 30 days. Piglets were inoculated with $5 \mathrm{ml}$ of the inoculum (see above), as $1,0 \mathrm{ml}$ intranasal $(0,5 \mathrm{ml}$ in each nostril) and $4,0 \mathrm{ml}$ intraperitoneally. Serum samples from inoculated piglets were collected before challenge and weekly for a period of 4 weeks and at necropsy in order to test serum-conversion by the PRRS ELISA 
test. Those pigs were observed daily for PRRS clinical signs (fever, anorexia, diarrhea, and other respiratory symptoms). At necropsy, all of the swine were thoroughly examined, blood, serum and organs were collected for histopathology and virological tests. The pigs were euthanized at the necropsy room by electrocution and a complete necropsy was performed immediately. Samples of tissues, including brain, lung, lymph nodes (superficial inguinal and mesenteric), tonsils, heart, kidney, liver, intestines, spleen and thymus were fixed in ten per cent buffered formalin. They were embedded in paraffin, sectioned at $5 \mu \mathrm{m}$ thick and stained with hematoxylin and eosin for light microscopical examination. Samples of tissues, blood and sera were also collected for viral isolation and RTPCR.

\section{RESULTSAND DISCUSSION}

The goals of this work were to perform a survey for PRRSV antibodies in Brazilian domestic swine, investigate possible positive results by more specific tests and also to implement diagnostic analysis in our laboratories for further PRRSV monitory. Although this was a preliminary study, it comprehended swine herds from major swine production States in Brazil (ABIPECS, 2003) and the sampling used in this study was obtained from swine herds from the 08 states which officially imported genetic material from countries where PRRS was endemic. Thus, we understood that the only way that the PRRSV could enter in Brazil was by importation of semen or live pigs, as occurred in another South American, and other countries around the world (DEWEY 1999; NARANJO, 2001). Thus, this surveillance was based in a concern of the swine producers, veterinarians and technical personnel from the Animal Health Defense Secretary from the Brazilian Agriculture, Animal Production and Food Supply Ministry.

The occurrence of single reactors in those studied herds moved us to develop and to establish complementary and more sensitive laboratorial diagnostic tests. We were able to implement techniques to identify PRRSV RNA or to perform viral isolation in vitro (tissue culture cells) or in vivo (swine bioassay) in those suspicion samples positive by ELISA. Figure 1 shows the description of the PRRS survey.

\section{Seroprevalence of PRRSV in studied Brazilian swine herds}

All 3442 serum samples were tested by the HerdChek* PRRS IDEXX ELISA test. The positive samples were re-tested in at least two independent tests. From the tested animals, 27 samples $(0.78 \%)$ were positive [sample to positive ratio $(\mathrm{S} / \mathrm{P})=0.4$ ] by the ELISA test and 04 samples $(\mathrm{S} / \mathrm{P}>0.2$ and $=0.4)$ were suspicion, totaling 31 positive/suspicion samples [0.9\% (Apparent Prevalence $=$ ApP) $]$ and $3411(99.1 \%)$ negatives. The test manufacturers affirm that this test is able to detect antibodies for both American and European PRRSV serotypes. They also inform that their test offers a sensitivity (Se) of 1.0 and specificity (Sp) of 0.995 with positive samples reaching a $\mathrm{S} / \mathrm{P} \geq$ 0.4 (COLLINS et al, 1996). With these characteristics it is estimated that the actual prevalence (AcP) is $0.4 \%$, (PIFFER \& GUIDONI, 1997). In addition to that, with this prevalence, the predictive positive value for this test is $55 \%$ as the predictive value for the negative sample is 1.0. This indicates that the probability of a positive serum to be really positive is equal to $55 \%$.

$$
\begin{aligned}
& A c P=\frac{A p P+S p-1}{S e+S p-1} \\
& A c P=\frac{0,009+0,995-1}{1+0,995-1} \\
& A c P=0,4 \%
\end{aligned}
$$

In other words, the predictive values measure the confidence of the test and they depend, not only in the test characteristic but also in the prevalence, which is very low or null (PIFFER \& GUIDONI, 1997). The hypothesis of the nullity of the serologic prevalence of this test for PRRS was confirmed when all positive samples from the IDEXX ELISA test were submitted to the CIVTEST ${ }^{\mathrm{TM}}$ SUIS PRRS (HIPRA), when all results were negative, following the criteria for positively or negativity recommended by the manufacturer. Considering that PRRS is a disease of high contagiously, if this disease existed in our herds, the prevalence indices would be superior to those found in this study. A second sampling of serum was performed with 343 samples of suspicion animals (litters and close contacts). Serum samples from farms of three Brazilian states were received. Following the retest of the five retested farms, only seven animals resulted positive.

\section{Viral isolation}

All serum samples from pigs positive/ suspicion on the ELISA test, swine organs, PBMC from blood and tonsil fragments from biopsies were inoculated in PRRSV susceptible tissue culture cells 


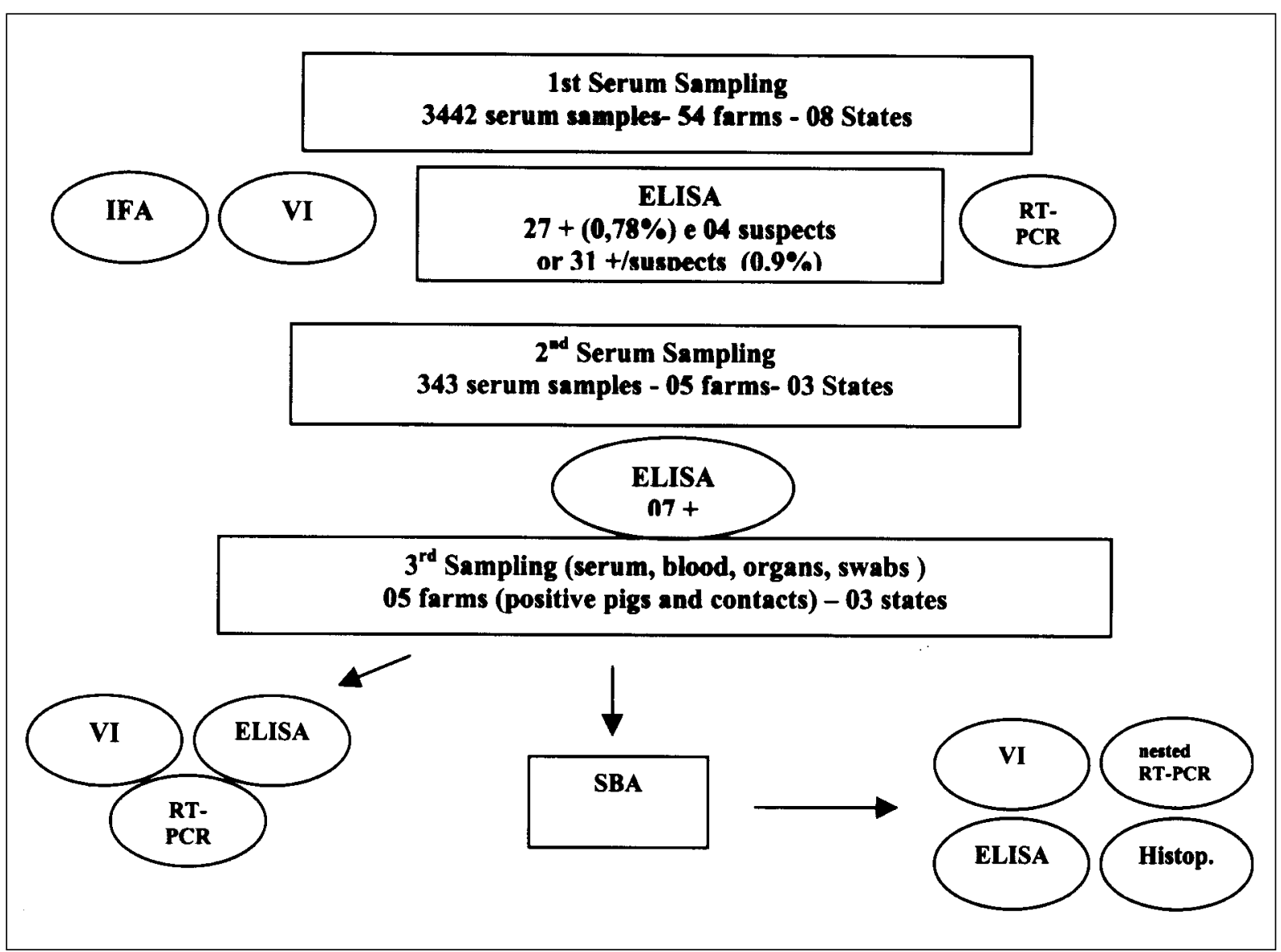

Figure 1 - Description of PRRS Survey ( MAPA and Embrapa 1999 - 2000)

Serum samples were collected, and ELISA test was performed. All positive or suspicion samples were retested and a second serum sample from those positive pigs (including litter and close contacts) was requested and tested by ELISA. Those samples were also analyzed in parallel by viral isolation (VI), reverse transcriptase polimerase chain reaction (RT-PCR) and by imunofluorescence (IFA). Farms in which pigs remained positive were monitored and the collection of additional materials for lab tests was requested. Besides tonsil biopsies, serum samples, blood and swabs (nasal, vaginal, pharyngeal) were also collected from suspicious pigs, from its litter (in the case to be female), and from their contacts. The received material was submitted to the same laboratory tests in addition to the swine bioassay (SBA). The inoculated animals from swine biossay were observed for a period of 1 month for clinical symptoms. During this experiment, serum samples from inoculated piglets were collected weekly and serology was performed (ELISA for PRRS) to verify if these pigs seroconverged. At the end of the experiment, pigs were euthanized and analyzed by histopathology (histop.), ELISA, viral isolation and RT-PCR (and nested RT-PCR).

MARC-145. No cytopathic effect (CPE) was observed even after 7 days pi. Negative results indicate the absence of infective virus particles due to negative PRRSV samples, or absence of viremia at the moment of blood collection or virus inactivation due the inadequate conservation of the swine samples.

\section{Immunofluorescence antibody test (IFA) for PRRSV}

None of the 38 serum samples tested were positive at the IFA test. Those samples included the 31 positive/suspicion samples and seven negative serum samples at the ELISA test.

\section{Swine bioassay}

Piglets were inoculated IP with an inoculum (pool of collected samples) prepared from material collected from five herds in which seven pigs resulted positive at the ELISA test. For the period of four weeks, none of the inoculated piglet presented characteristic PRRS symptoms and the ELISA test for all weekly tested pigs was negative. This result indicates that no serum-conversion occurred. At the end of the experiment, no pathological lesions (macro or microscopic) were found. Furthermore, virological and molecular examinations indicated no evidence of viable 
virus particles at the viral isolation on MARC-145 cells or PRRSV RNA by RT-PCR using ORF7 primers.

\section{RT-PCR for PRRSV}

All RNA samples from positive serum at the ELISA test, swine organs from positive pigs at the ELISA test and from piglets from the swine bioassay were negative. No amplification was detected also when a different set of primers (nested RT-PCR) was used. figure 2 shows an example of the RT-PCR assay for PRRSV that was carried out on routine. All of those samples were from pigs positive at the ELISA test.

\section{CONCLUSIONS}

The serological tests performed in the joint EMBRAPA and MAPA study indicated a prevalence less than $0.4 \%$ in the tested swine population, and this number does not fit with the epidemiological characteristics of PRRSV around the world. All samples tested by RT-PCR and viral isolation were also negative. It is important to mention that those results are from surveys carried out on swine farms, which originated from the major swine producing States in Brazil. In spite of the fact that some serum samples have given positive results using the ELISA

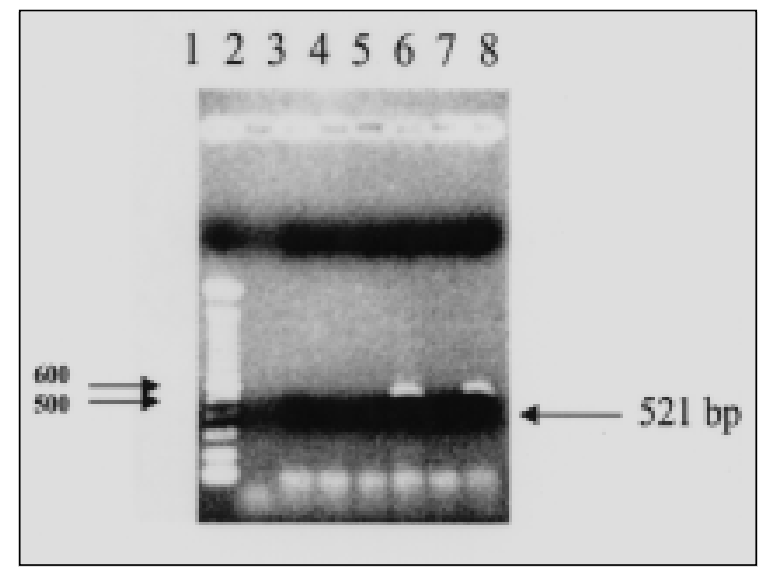

Figure 2 - RT-PCR for detection of PRRSV's RNA.

RT-PCR electrophoresis gel from serum samples of swine positive at the ELISA PRRS test using oligonucleotide primers which amplify a $521 \mathrm{bp}$ sequence of the ORF7 conserved sequence, which encodes a viral nucleocapsid protein. Line 1 is molecular weight marker of 100 base pairs. Lines 2, 3, 4 and 5 (samples 1, 2, 3, 4) are serum samples positive at the ELISA for PRRSV antibodies. Lines 6 and 8 are positive controls for the RT-PCR and PCR (positive cDNA) respectively. Line 7 is the negative control (Diethyl Pirocarbonate water). test, we have no knowledge of an outbreak or even clinical diagnosis, viral isolation or detection of PRRSV RNA in Brazil. Although our results indicate no evidence of the PRRS in Brazil, which give a positive advantage face other swine producing countries, it is necessary to constantly monitor Brazilian swine populations to avoid the introduction and dissemination of this virus in the Brazilian herds.

\section{REFERENCES}

ABIPECS - Suinocultura Brasileira. Capturado em 28 mar. 2003. Online. Disponível na Internet: http:// www.abipecs.com.br/suinocultura.htm.

ALLENDE, R. et al. Porcine reproductive and respiratory syndrome virus: Description of persistence in individual pigs upon experimental infection. Journal of Virology, v.74, n.22, p.10834-10837, 1999.

CHOMCZYNSKI, P.; SACCHI, N. Single step methods of RNA isolation by acid guanidinum thiocyanate-phenolchloroform extraction. Analytical Biochemistry, v.162, p.156-159, 1987.

CHRISTOPHER-HENNINGS, J. et al. Detection of porcine reproductive and respiratory syndrome virus in boar semen by PCR. Journal of Clinical Microbiology, v.33, p.17301734, 1995.

CIACCI-ZANELLA, J.R. Ausência de ocorrência do vírus da síndrome reprodutiva e respiratória dos suínos (PRRS) no rebanho suíno do Brasil. In: CONGRESSO BRASILEIRO DE VETERINÁRIOS ESPECIALISTAS EM SUÍNOS, 10., 2001, Porto Alegre, RS. Proceedings... Concórdia : Embrapa Suínos e Aves, 2001. v.1, p.182-186.

COLLINS, J.E. et al. Isolation of swine infertility and respiratory syndrome virus in North America and experimental reproduction of the disease in gnotobiotic pigs. Journal of Veterinary Diagnostic Investigation, v.4, p.117-126, 1992.

COLLINS, J. et al. Laboratory diagnosis of porcine reproductive and respiratory syndrome (PRRS) virus infection.. Swine Health and Production, v.4, n.1, p.3339, 1996.

DEE, S.; MOLITOR, T. Elimination of porcine reproductive and respiratory syndrome virus using a test and removal process. Veterinary Record, v.143, p.474-476, 1998.

DEWEY, C. Global PRRS. In: ALLEN D. LEMAN SWINE CONFERENCE, 1997, Saint Paul. Proceedings... Ni:University of Minnesota, 1997. V.24, p.28-32.

DEWEY C. The porcine reproductive and respiratory syndrome panzootic. The Compendium on Continuing Education for the Practicing Veterinarian, v.20, n.2, p.S82-S96, 1998..

DEWEY, C. History, occurrence, dynamics and current status of PRRS in North America, Latin America and Asia. In: SYMPOSIUM OF THE ERADICATION OF PRRS AND 
AUJESZKY'S DISEASE, $3^{\text {rd }}$, 1999, Ploufragan, France. Proceedings... France, 1999. p189-193.

DONE, S.H.; PATON, D.J.; WHITE, M.E.C. Porcine Reproductive and respiratory syndrome (PRRS): a review, with emphasis on pathological, virological and diagnostic aspects. The British Veterinary Journal, v.152, p.153-174, 1996.

GOYAL, SM. Porcine reproductive and respiratory syndrome. Journal of Veterinary Diagnostic Investigation, v.5, p.656-664, 1993.

KEFFABER, K.K. Reproductive failure of unknown etiology. American Association of Swine Practitioners Newsletter, v.1, p.1-9, 1989.

KIM, H.S. et al. Enhanced replication of porcine reproductive and respiratory syndrome (PRRS) virus in an homogeneous subpopulation of MA-104 cell line. Archives of Virology, v.133, p.477-483, 1993.

MENG, X.-J. et al. Phylogenetic analysis of the putative M (ORF6) and $\mathrm{N}$ (ORF7) genes of porcine reproductive and respiratory syndrome virus (PRRSV): implication for the existence of two genotypes of PRRSV in the USA and Europe. Archives of Virology, v.140, p.745-755, 1995.

MENGELING W.L., LAGER, K.M., VORWALD, A.C. Diagnosis of porcine reproductive and respiratory syndrome. Journal of Veterinary Diagnostic Investigation, v.7, p.316,1995

MENGELING W.L. et al. Diagnosis of porcine reproductive and respiratory syndrome using infected alveolar macrophages collected from live pigs. Veterinary Microbiology, v.49, p.105-115, 1996

MEULENBERG, J.J.M.; HULST, M.M.; DE MEIJER, E.J. Lelystad virus, the causative agent of porcine epidemic abortion and respiratory syndrome (PEARS), is related to LDV and EAV. Virology, v.192, p.62-72, 1993.

NARANJO, J.Y. Informativo preliminar sobre o diagnóstico da situação do PRRS no Chile. In: I CONFERÊNCIA VIRTUAL GLOBAL SOBRE SAÚDE DE SUÍNOS, 2001. Online. www.conferencia.uncnet.br/swine/ swine.html. 2001. CD-Rom.

NORTH, J.; HENRY, C. One-step gradient separation of rosetted cells. In: MISHELL, B.B.; SHIIGI, S. M. Selected methods in cellular immunology. San Francisco : Freeman, 1980. Chap.8, p.205-208.

PIFFER, I.; GUIDONI, A.L. Diagnóstico sorológico: títulos, testes e verdades - uma interpretação racional. In: CONGRESSO BRASILEIRO DE VETERINÁRIOS ESPECIALISTAS EM SUÍNOS, 8., 1997, Foz do Iguaçú, PR. Proceedings... Concórdia : Embrapa Suínos e Aves, 1997. p.95-96.

SWENSON, S.L. et al. Excretion of porcine reproductive and respiratory syndrome virus in semen after experimentally induced infection in boars. Journal of the American Veterinary Medical Association, v.204, p.1943-1948, 1994.

WENSVOORT, G. et al. Mystery swine disease in the Netherlands: the isolation of Lelystad virus. Veterinary Quarterly, v.13, p.121-130, 1991. 